\title{
ABSTRAK \\ PERANAN PEREMPUAN DALAM PENINGKATAN PENDAPATAN RUMAH TANGGA MISKIN DI DUSUN FAIR KECAMATAN DULLAH SELATAN KOTA TUAL
}

\author{
Johanis Paulus \\ Toatubun, Dosen STIA Darul Rachman Tual, \\ E-mail: john.figotoatubun@gmail.com
}

\begin{abstract}
Abstarak: Salah satu fenomena yang menarik pada rumah tangga miskin dalam mempertahankan hidup, yaitu pada sisi pendapatan mereka terpaksa melakukan pengoptimalan pendapatan melalui pengerahan sumber daya ekonomi yang dimiliki. Penelitian ini bertujuan untuk mengetahui sejauhmana peranan perempuan/istri di suatu rumah tangga miskin dalam membantu suami mereka menopang kehidupan rumah tangga mereka. Dengan menggunakan teknik analisis kualitatif, diketahui bahwa para istri dalam suatu rumah tangga miskin terpaksa harus sebagian besar waktunya untuk mengurus rumah tangga, dan terjun ke dunia kerja yang pada umumnya pada sektor informal karena hanya berbekal pengetahuan dan ketrampilan yang minim untuk membantu suami mereka dalam menghidupi rumah tangga.
\end{abstract}

\section{Kata Kunci: Perempuan, Kemiskinan, Pendapatan.}

Wanita mempunyai potensi dalam memberikan kontribusi pendapatan rumah tangga, khususnya rumah tangga miskin. Dalam rumah tangga miskin, anggota rumah tangga wanita terjun ke pasar kerja untuk menambah pendapatan rumah tangga yang dirasakan tidak cukup. Menurut Ihromi, T.O. (2000), secara umum perempuan memiliki tiga fungsi utama yang sangat berkaitan dengan kedudukan dan peran wanita yaitu fungsi reproduksi, fungsi sosialisasi dan fungsi produksi. Terkait dengan fungsinya yang ke tiga yaitu fungsi produksi, maka menurut pendapat Rahma Sugiharti dalam (Suyanto \& Hendrarso, 2006) mengatakan bahwa perempuan sesungguhnya merupakan sumber daya ekonomi yang tidak kalah pentingnya dibandingkan dengan pria. Keberadaan perempuan dalam rumah tangga bukan sekedar sebagai pelengkap fungsi reproduksi saja, namun lebih dari itu perempuan terbukti memberikan sumbangan yang besar bagi kelangsungan ekonomi dan kesejateraan rumah tangga serta masyarakat.

Dalam keluarga miskin, pada umumnya seluruh sumber daya manusia dikerahkan untuk memperoleh penghasilan, sebagai upaya pemenuhan kebutuhan pokok sehari-hari. 
Oleh sebab itu dalam keluarga miskin menganggur merupakan sesuatu yang mahal, karena anggota keluarga lain yang bekerja atau menjadi beban tanggungan anggota rumah tangga lain. Mereka tidak sempat menganggur dan mereka bersedia melakukan pekerjaan apapun, terutama sektor informal yang tidak membutuhkan keahlian tertentu, mudah untuk dimasuki, luwes, dan tidak membutuhkan modal yang besar.

Berkaitan dengan pengerahan sumber daya ekonomi yang dimiliki rumah tangga miskin, maka telah menuntut wanita sebagai istri untuk dapat menopang ketahanan ekonomi keluarga. Kondisi demikian merupakan dorongan yang kuat bagi wanita untuk bekerja di luar rumah. Dalam beberapa tahun terakhir ini keterlibatan wanita pada sektor publik menunjukkan angka yang terus meningkat. Hal ini menunjukkan bahwa motivasi wanita untuk bekerja di sektor publik semakin tinggi. Wanita pada rumah tangga miskin, rata-rata mempunyai tingkat pendidikan yang relatif rendah karena kondisi ekonomi yang melatarbelakanginya. Mereka masuk ke pasar kerja dengan tingkat pendidikan rendah dan ketrampilan rendah. Wanita dengan tingkat pendidikan dan ketrampilan yang rendah inilah yang justru banyak masuk ke lapangan kerja, terutama pada sektor informal dengan motivasi menambah pendapatan keluarga.

Sumbangan ekonomi dari kegiatan ekonomi perempuan mempunyai arti penting, terutama pada keluarga miskin. Pekerjaan-pekerjaan yang dimasuki perempuan adalah menjadi pengumpul bahan makanan/produksi, pengolahan hasil pertanian/perikanan, pekerja diperusahaan atau industri rumah tangga untuk pengolahan hasil pertanian/perikanan, pedagang eceran, dan pemilik warung. Perempuan-perempuan yang terlibat dalam aktivitas pencari nafkah merupakan pelaku aktif perubahan sosial ekonomi.

Fenomena kehidupan rumah tangga miskin dengan keterlibatan para istri/ibu rumah tangga dalam kegiatan ekonomi, sebetulnya terjadi di hampir seluruh wilayah, namun sebagai sampelnya, maka pada penelitian ini, lokasi yang diambil adalah di Dusun Fair, Kecamatan Dullah Selatan, Kota Tual. Dusun ini terletak atas sebuah pulau tersendiri dengan jarak sekitar $2 \mathrm{~km}$ dari Pulau Dullah, pusat Kota Tual. Dusun ini dihuni oleh penduduk yang berasal dari berbagai suku dan etnis yang memiliki beragam mata pencaharian. Di dusun tersebut, terdapat 580 kepala keluarga (kk) dari total 1.111 kepala keluarga yang tergolong sebagai rumah tangga miskin. Data rumah tangga miskin yang 
digunakan disini adalah data jumlah kepala keluarga yang tedaftar sebagai penerima beras raskin. Data ini digunakan karena hanya inilah satu-satunya data sekunder yang tersedia terkait jumlah rumah tangga miskin.

Adapun mata pencaharian para kepala keluarga yang tergolong sebagai rumah tangga miskin tersebut adalah bermacam-macam. Ada sebagian yang bermata pencaharian sebagai nelayan tradisional, ada yang berprofesi sebagai petani, sebagai buruh kasar, sopir, tukang ojek dan berbagai profesi lain yang sering kali tidak tetap; disesuaikan dengan kondisi dan peluang yang ada. Keadaan mata pencaharian seperti yang digambarkan di atas, menyiratkan keadaan penghasilan yang sering kali tidak cukup untuk memenuhi kebutuhan dasar keluarga. Kondisi ini mendorong para istri untuk turun tangan membantu suami mereka dalam mencari nafkah. Ada sebagian yang membantu pekerjaan/usaha yang dikerjakan suaminya seperti menjual hasil tangkapan, menjemur/mengeringkan rumput laut bagi para istri nelayan; membantu mengelola kebun; dan lain-lain pekerjaan yang disesuaikan dengan pekerjaan sang suami. Namun ada pula yang berusaha mencari sumber penghasilan/pekerjaan lain diluar yang dikerjakan sang suami. Semua pekerjaan ini sengaja bahkan cenderung terpaksa dilakukan para istri rumah tangga miskin tersebut dalam rangka membantu suaminya menghidupi keluarga.

\section{METODE PENELITIAN}

\section{Lokasi dan Informan Penelitian}

Penelitian ini berlokasi di Dusun Fair Kecamatan Dullah Selatan Kota Tual. Mengingat jumlah keluarga miskin di lokasi penelitian cukup banyak sehingga dalam rangka mendapatkan data, maka dalam penelitian ini, diambil beberapa orang dari antara ibu rumah tangga miskin untuk dijadikan informan kunci

\section{Teknik Analisa Data}

Seluruh hasil data yang akan dikumpulkan ataupun diperoleh dalam penelitian ini akan dianalisa secara kualitatif. Menurut Taylor (1995) Dalam penelitian kualitatif, data yang muncul hanyalah berupa kata-kata yang dapat dianalisa nelalui 3 alur kegiatan yaitu: Pertama, Reduksi data. Reduksi data dapat diartikan sebagai proses pemilihan, pemusatan 
perhatian, penyederhanaan, pengabstrakan dan transformasi data yang muncul dari catatan-catatan tertulis di lapangan. Kedua, Penyajian Data. Pada tahap ini, data-data disajikan sebagai sekumpulan informasi yag tersusun yang memberikan kemungkinan tentang adanya penarikan kesimpulan dan pengambilan tindakan, gambar ataupun tabeltabel yang menjelaskan fenomena-fenomena yang diteliti untuk dijadikan deskripsi dan argumentasi agar mudah dipandu. Dan ketiga, Penarikan Kesimpulan Dan Verifikasi, yaitu merupakan bagian akhir dari penelitian. Peneliti mencari arti-arti, pola-pola dan konfigurasi yang mungkin, sebab akibat yang menuju kepada kebenaran, kekokohan dan faliditas. Selanjutnya interpretasi akan memberi makna kepada data, menjelaskan pola dan mencari hubungan-hubungan antar berbagai konsep.

\section{HASIL DAN PEMBAHASAN}

\section{Keterlibatan Istri dalam Mencari Nafkah}

Di tengah-tengah berbagai kebutuhan rumah tangga yang harus dipenuhi, sementara penghasilan kepala rumah tangga yang tergolong pas-pasan, atau bahkan tidak cukup, mendorong adanya upaya pemanfaatan sumber daya lain yang tersedia untuk membantu memperoleh penghasilan untuk memenuhi berbagai kebutuhan hidup tersebut. Di dalam keluarga miskin, ibu rumah tangga seringkali menjadi satu-satunya alternatif sumber daya yang dapat dimanfaatkan untuk membantu suaminya dalam hal mencari tambahan penghasilan untuk memenuhi kebutuhan rumah tangganya. Ibu rumah tangga terpaksa harus keluar rumah untuk membantu suaminya mencari nafkah dalam hal memenuhi kebutuhan keluarganya.

Pekerjaan yang digeluti seorang ibu rumah tangga miskin, selalu bermacammacam, ada yang sekedar membantu pekerjaan suaminya, seperti berkebun, apabila suaminya seorang petani, membantu suami menjemur hasil panen rumput laut, apabila suaminya seorang petani rumput laut, atau kegiatan lainnya yang sifatnya membantu pekerjaan suaminya. Selain jenis pekerjaan seorang ibu rumah tangga yang membantu usaha suaminya, ada juga ibu rumah tangga yang membantu suaminya mencari nafkah dengan bekerja pada bidang usaha lain yang tidak sama dengan usaha sang suami, yaitu misalnya ada yang berprofesi sebagai buruh pembersih Kota Tual, pedagang asongan, 
pedagang kaki lima di pasar, pembantu rumah tangga, atau pekerjaan sambilan lain yang disesuaikan dengan peluang yang ada.

\section{Bertambahnya Beban Kerja Para Ibu Rumah Tangga}

Telah menjadi tradisi sebagian besar masyarakat, bahwa keperluan harian rumah tangga seperti mencuci, membersihkan rumah, memasak, merawat anak, dan berbagai kesibukan lain di rumah adalah tanggung jawab seorang istri/ibu rumah tangga; sedangkan sang suami hanyalah bertanggung jawab terhadap urusan mencari nafkah. Kebiasaan yang bahkan telah membudaya bagi sebagian besar masyarakat ini mengakibatkan seorang ibu rumah tangga memiliki beban kerja yang tidak sedikit di dalam rumahnya.

Berbagai kesibukan disertai dengan beban kerja yang tidak sedikit ini, terasa semakin bertambah berat manakala sang ibu rumah tangga tersebut harus terjun ke lapangan pekerjaan mencari nafkah membantu suaminya. Mereka harus menjalani dua fungsi sekaligus; sebagai ibu rumah tangga yang harus menyiapkan segala sesuatu keperluan anak dan suaminya, dan fungsi sebagai pencari nafkah bagi keluarganya. Hasil penelitian ini menggambarkan beratnya beban kerja seorang ibu rumah tangga miskin apabila harus bekerja mencari nafkah membantu suaminya.

\section{Sedikitnya Alokasi Waktu Para Istri dalam Mengurus Rumah Tangga}

Seperti yang telah disebutkan diatas bahwa para istri/ibu rumah tangga secara kodrati, telah menjadi tanggung jawabnya untuk mengurus segala macam keperluan rumah tangga. Kegiatan-kegiatan seperti memasak, mencuci, membersihkan rumah, merawat anak, dan lain-lain adalah tanggung jawab seorang ibu rumah tangga. Namun karena tuntutan berbagai kebutuhan hidup yang tidak dapat dipenuhi oleh suami mereka sehingga terpaksa mereka turut membantu suami mencari nafkah. Di dalam keluarga miskin yang para istri/ibu rumah tangganya terpaksa harus menjadi pekerja di berbagai sektor untuk membantu suaminya mencari nafkah, tentu saja sebagian besar dari waktunya dialokasikan di luar rumah untuk bekerja mencari nafkah. Dengan demikian, sisa waktu untuk aktivitas mengurus rumah, menjadi sedikit. Mereka terpaksa harus mengorbankan sebagian besar waktu yang seharusnya diperuntukan bagi urusan rumah tangga, karena sebagian besar waktu harus dicurahkan bagi pekerjaannya di luar rumah. 


\section{Adanya Tambahan Penghasilan Karena Keterlibatan Istri dalam Membantu Suami}

Keterbatasan penghasilan suami/kepala rumah tangga sebuah rumah tangga miskin, mendorong istri/ibu rumah tangga terjun ke lapangan kerja untuk membantu suaminya mencari nafkah. Keterbatasan kemampuan suami mereka dalam mencari nafkah, mendorong mereka berinisiatif sendiri untuk mencari penghasilan demi menghidupi keluarga mereka. Keterlibatan seorang ibu rumah tangga dalam mencari nafkah, diharapkan dapat membantu menambah penghasilan keluarga.

Dari penjelasan yang disampaikan para responden, diketahui adanya tambahan penghasilan dalam sebuah keluarga miskin karena keterlibatan istri dalam membantu suaminya mencari tambahan penghasilan. Hasil jerih paya para ibu rumah tangga tersebut menjadi sangat berarti bagi kelanjutan hidup keluarga mereka. Dalam kehidupan yang serba kekurangan, apalagi seringkali disertai dengan keadaan para suami yang sering menganggur karena tidak mendapat pekerjaan, mengakibatkan peran aktiv para istri dalam mencari nafkah tersebut menjadi sangat penting bagi kelangsungan hidup keluarga mereka.

\section{Terpenuhinya Berbagai Kebutuhan Dasar Rumah Tangga Karena Keterlibatan Istri Dalam Membantu Suami}

Keluarga miskin biasanya didefinisikan sebagai ketidakmampuan memenuhi berbagai kebutuhan dasar hidup mereka. Dengan berbagai keterbatasan yang mereka miliki, mengakibatkan mereka seringkali kesulitan dalam memenuhi kebutuhan dasar hidup mereka. Mereka para keluarga miskin, bahkan sering kali harus pasrah untuk tidak terpenuhi kebutuhannya karena ketidakmampuan mereka. Rasa sakit, lapar atau bahkan pakaian yang dibutuhkan sering kali harus ditahan untuk tidak dipenuhi karena ketidakmampuan mereka.

Fenomena kemiskinan seperti yang diuraikan diatas merupakan suatu ciri khas yang tak dapat dipisahkan dari kehidupan keluarga miskin. Kebutuhan hidup yang terus bertambah, sementara biaya hidup yang terus tinggi, mendorong orang berlomba-lomba memenuhi kebutuhan hidup tersebut. Sesuai hasil penelitian, ditemukan bahwa para istri dari keluarga miskin memiliki andil yang besar terhadap usaha mereka memenuhi berbagai kebutuhan dasar mereka. Penghasilan suami yang semula hanya untuk 
kebutuhan tertentu saja, kini dengan adanya peran aktiv para istri dalam mencari nafkah, maka berbagai kebutuhan dasar yang semula tidak dapat dipenuhi menjadi terpenuhi, walaupun dari pengakuan beberapa responden, diketahui bahwa sering kali mereka masih tetap merasa kurang terhadap apa yang diusahakan selama ini. Penghasilan yang diterima dari hasil usaha membantu suami dalam mencari nafkah, kadang-kadang terasa kurang. Biaya hidup yang terus tinggi, dengan berbagai tawaran akan gaya hidup yang serba mengikuti trend modern, mengakibatkan mereka yang telah berusaha bekerja membantu suami dalam mencari nafkah, selalu kesulitan untuk memenuhi berbagai kebutuhan tersebut.

\section{KESIMPULAN}

1. Di dalam keluarga miskin, ibu rumah tangga seringkali menjadi satu-satunya alternatif sumber daya yang dapat dimanfaatkan untuk membantu suaminya dalam hal mencari tambahan penghasilan untuk memenuhi kebutuhan rumah tangganya. Ibu rumah tangga terpaksa harus keluar rumah untuk membantu suaminya mencari nafkah dalam hal memenuhi kebutuhan keluarganya.

2. Beban kerja seorang ibu rumah tangga miskin, tidaklah ringan. Mereka harus menjalani dua fungsi sekaligus; sebagai ibu rumah tangga yang harus menyiapkan segalah sesuatu keperluan anak dan suaminya, dan fungsi sebagai pencari nafkah bagi keluarganya.

3. Adanya tambahan penghasilan dalam sebuah keluarga miskin karena keterlibatan istri dalam membantu suaminya mencari tambahan penghasilan. Hasil jerih paya para ibu rumah tangga tersebut menjadi sangat berarti bagi kelanjutan hidup keluarga mereka.

\section{SARAN}

1. Hasil penelitian menunjukan bahwa di dalam keluarga rumah tangga miskin, seorang istri sering kali menjadi tulang punggung keluarga dalam hal mencari nafkah. Ini berarti bahwa mereka dalam kondisi yang rapuh. Oleh karena itu, disarankan kepada pihak pemerintah daerah untuk mengusahakan berbagai program yang dapat 
membantu para keluarga miskin ini agar dapat segera keluar dari kemiskinan yang membelenggu mereka selama ini.

2. Bagi para keluarga miskin, agar jangan berputus asa, tetapi sebaliknya terus berjuang menemukan sumber penghasilan yang lebih baik agar dapat ningkatkan derajat kehidupan mereka.

\section{DAFTAR PUSTAKA}

Apriadji. 2002. Menyongsong Kiat Baru Pemberdayaan Keluarga Di Indonesia. Yayasan Dana Sejahtera Mandiri Damandiri. Jakarta.

Fakih Mansour. 2002. Analisis Gender dan Tranformasi Sosial. Pustaka Pelajar. Yogyakarta.

Gardiner - Oey, Mayling, dkk. 1999. Perempuan Indonesia Dulu dan Kini. Gramedia Pustaka Utama. Jakarta.

Hardiansyah. 2005. Sumber Daya Manusia, Peluang Kerja dan Kemiskinan. Tirta Wacana. Jogjakarta.

Ihromi, T.O. (2000). Kajian Wanita Dalam Pembangunan. Yayasan Obor Indonesia. Jakarta.

Kuncoro Mudrajad. 2010. Masalah, Kebijakan, dan Politik Ekonomika Pembangunan. Penerbit Erlangga. Jakarta

Listiani, dkk. 2002. Gender \& Komunitas Perempuan Pedesaan (Kondisi Nyata yang Terjadi di Lapangan). Bitra Indonesia. Medan.

Rais Amien. 1995. Kemiskinan Dan Kesenjangan Di Indonesia. Aditya Media. Yogyakarta.

Sumardi dan Han Dieter-Evers. Kemiskinan dan Kebutuhan Pokok. Rajawali Press. Jakarta.

Sumitro. 1999. Kemiskinan dan Keberfungsian Sosial- Studi Kasus Rumah Tangga Miskin di Indonesia. STKS Press. Bandung.

Suyanto. Bagong \& Hendrarso. Susanti. Emy. 2006. Wanita Dari Subordinasi dan Marginalisasi Menuju ke Pemberdayaan. Airlangga University Press. Surabaya.

Taylor. 1995. Teknik-teknik Analisa Data. Sinar Harapan. Surabaya.

Todaro. Michael P., and Stephen C Smith. 2006. Pembangunan Ekonomi. Edisi Kesembilan. Terjemahan. Erlangga, Jakarta. 